\title{
Discussion on vocational education in China and Germany from the perspective of college-enterprise cooperation
}

\author{
Huizi Sun \\ Institute of Higher Education, Beihang University, Beijing 100191, China. \\ 897600466@qq.com
}

Keyword: college-enterprise cooperation, vocational education, curriculum

\begin{abstract}
Vocational education is crucial in improving the quality of workers in our country, and promoting and accelerating the development of productive forces. But in the actual vocational education, there is disjunction between theoretical learning and practice. From the angle of the cooperation between schools and enterprises, this paper makes a contrastive analysis on the education system, the main body participation, the curriculum, the teaching staff and the teaching mode of the vocational education in China and Germany. In the light of issues of the present situation of vocational education in China, this thesis then set out to provide some advices.
\end{abstract}

\section{Introduction}

With the development of society, the development of higher vocational education has become an important way to promote the development of national productive forces. How to deepen the reform of education mechanism in higher vocational education, so that the personnel of vocational education can really play its due role in the development of enterprises to provide human resources support has become the current issue that higher vocational education should be considering. Higher vocational education involves a wide range of issues, and is a complex system. When we carry out the reform of higher vocational education, we should combine with China's national conditions, and use rationally of foreign mature experience. This paper intends to explore the vocational education between China and Germany from the perspective of the cooperation between schools and enterprises. In the field of vocational education, Germany has already has the mature experience of school-enterprise cooperation.

\section{Analysis on Similarities and Differences of Vocational Education between China and Germany}

\subsection{Vocational Education System}

Germany's vocational education is mainly managed by the government's economic department, and some of the higher vocational and technical colleges are managed by the cultural departments of the state government. In Germany, after graduating from junior high school, students find their favorite enterprises to work. According to their own units need, enterprises send them to the appropriate vocational schools to learn. Students work, while learning, with tuition paid by the enterprise. 【1】students pick up theoretical knowledge and practical skills in the process of learning. Upon graduation, students will receive a diploma issued by the school and an IHK certificate issued by the Chamber of Commerce and Industry. When they obtain these two certificates, they can tranfer the "apprenticeship" into ordinary workers.

In China, vocational education and general education are parallel form of education, it can be divided into secondary vocational education and higher vocational education, the majority of which is under the management of the education sector. Students enter the school for learning through secondary or higher school uniform entrance examination organized by the nation. In the study period, they pay a certain amount of tuition, after graduation recommended by the school to work or self-careers. With the change of the idea of higher vocational education, some vocational colleges 
began to seek cooperation with enterprises. The main form of which for students is in school, and there is a period of time to enter the enterprise internship. After graduation students are recommended to enter the enterprise to work. The lack of relevant practical experience during the study period, the lack of motivation and purpose of students has become common problems in our country's higher vocational education.

\subsection{The Participation of Subjects in the Cooperation between Vocational Colleges and Enterprises}

In Germany, the government, business associations, schools and enterprises belong to the main part of the school-enterprise cooperation. Government is responsible for organization and management in the school-enterprise cooperation, and responsible for the development of curriculum standards and norms of cooperative behavior. The CCIB is responsible for overseeing the whole process of cooperation and for setting the school curriculum and the development of skills assessment standards. The enterprise is mainly responsible for the cultivation of students 'practical skills, and bears the responsibility of guiding students' internship activities. The school is mainly responsible for the teaching of theoretical study of students. The main learning time for students is to practice learning, accounting for $70 \%$ of the time, theoretical study only $30 \%$ of the time.

In China, the main learning time of vocational school students is in the school. Part of the practice of students is completed in the school's practice base or training room, part of is completed in the enterprise. Enterprises are mainly in line with the school's education work to complete a number of ancillary tasks. Because the government and the industrial and commercial association almost did not participate in, therefore the student lack the practice opportunity. Thus the student also cannot adapt to the need of the enterprises. And thus government and industrial and commercial associations play a bigger role in the school-enterprise cooperation is very necessary.

\subsection{Vocational Education Curriculum}

The curriculum of higher vocational school determines the main direction of teaching. Germany's vocational school curriculum is based on the needs of business decisions, determined by the government and trade unions. Students in the enterprise spent most of the time working, and they can work according to their own problems encountered in school learning, which provides the focus of learning and the purpose of learning. After students learned the theory of knowledge, they can immediately practice in the enterprise, thus contacting theoretical and practical. When the company's technology is updated, the courses students learn will also change.

In our country, the curriculum of higher vocational colleges is chosen independently by the vocational colleges. As for which type of businesses graduates will go to after graduation is not sure, so curriculum focuses on comprehensiveness. At the same time ensuring the comprehensiveness, it is difficult to ensure targeted and in-depth nature. With the demands of the professional market improving, vocational schools also began to take into account the development of enterprises in the course set, but vocational schools lack of sufficient sensitivity in the market survey, there is a certain lag behind in the curriculum-setting.

\subsection{The Construction of Teaching Staff in Vocational Education}

In Germany, students have dual instructors, one is the school teachers, mainly responsible for teaching students the theoretical knowledge, the other is the enterprise trainers, mainly responsible for guiding students to practice the operation. German vocational education teachers need a certain pre-job training and on-the-job training before going to work. To complete the pre-job, four to five years of professional knowledge of learning and educational theory of learning is necessary to obtain the appropriate diploma. And to carry out educational practice, they are required to be able to achieve an independent educational activities to the level of education and teaching seminars, and 
then through examination they obtain qualifications in the teaching profession. In the post-entry they also continue to receive continuing education, and continuous learning of theoretical knowledge to improve practical ability. [2] Some of the German states also require teachers to have a certain degree of professional-related professional experience. For the training of enterprises in the same requirements require profound professional knowledge and vocational training with the necessary theoretical knowledge of education. For these people, the Government also put forward higher requirements. In order to improve the training level of the trainees, the commercial guilds also provide training to the corporate trainers in order to improve their ability to guide students in practice.

In our country, the cooperative education between colleges and enterprises in higher vocational colleges has been explored accordingly. For example, the school proposed the construction of "double teacher" program. Teachers can not only teach good professional courses, but also the relevant aspects of practice. However, due to the definition of "dual teacher" has the issue of vagueness of qualification and other issues, making the work carried out not smooth enough. And teachers in the process of transformation are left lack of support for psychological transformation because of the lack of appropriate measures for teacher training. On the other hand, some colleges and universities in China have also put forward the "dual mentor" student training program, but the trainers suffer from the lack of appropriate theoretical quality, thus its more of a mere formality.

\subsection{The Teaching Mode of Vocational Education}

In the teaching mode, the German implemented the task-based inquiry model. First of all, students ask questions, so that students collect relevant information on the basis of clear objectives, then develop next work program, and then carry out the implementation of the program. Teachers are to guide and evaluate students in the work program. Students in the school already have the ability to complete the corresponding work independently. However, China's teaching model is still mainly students listen to the teachers. In the practice of education, it is still mainly teachers do the most, students imitate them. Classroom teaching and production practice are out of touch, students hands-on ability, independent thinking ability, work practice ability has not been developed.

\section{Enlightenment of Vocational Education Mode of School - enterprise Cooperation in Germany to China 's Vocational Education}

\subsection{The Government Plays a Good Role in the Overall Management of Vocational Education}

As a government to manage the country's macroeconomic affairs, it should play its own role of overall management. In Germany, the government in the school-enterprise cooperation in education plays a liaison, communication and coordination role. China should learn from it, the central government should take vocational education management as an important indicator of the evaluation of performance of the local government. Thus promoting the local governments to effectively fulfill their duties, to provide policy support for the development of education. The specific tasks of the government should include establishing the link between the enterprise and the school, providing a practical operation for the students' learning, establishing the evaluation scheme for the cooperative education between enterprises and schools, and supervising and managing the cooperation; Coordination of enterprises and schools in the emergence of contradictions in cooperation to ensure the smooth development of vocational education.

\subsection{Widen the Depth of School-Enterprise Cooperation}

According to China's current national conditions, because of the limited number of enterprises, students cannot determine the specific units of the future work, so there are still some difficulties in the implementation of dual-mode teaching model. School-enterprise cooperation education is mainly reflected in two aspects of the trainee and recommended employment. These are only the 
school-enterprise cooperation in the shallow level of education. In the future, school-enterprise cooperation education should be to the curriculum development, training base inside and outside the school construction and use, student practice guidance and other aspects, to achieve "theoretical study - professional training - theoretical guidance - production probation - - theoretical summary practice " like theory-and-practice-alternating learning model. This is also China's social development requirements. In China, some enterprises began to carry out "order-style" training of teaching experiments, funded by the enterprises to train students, in which students mainly learning the production of the necessary knowledge in school, but also participate in a certain production practice, thus they can directly go to the enterprise to work after graduation.

\subsection{Adjust Curriculum according to the Needs of Enterprises}

The purpose of education in China has clearly pointed out: "to combine education and productive labor, build the cause of socialism builders and successors." This is suitable for all types of schools in China, it is also one of the principles to comply with vocational colleges. Then how can we combine education and productive labor has become the problem that the majority of educators must pay attention to. Curriculum reform is the core of education reform. Higher vocational colleges set courses, the proportion of which should be based on the needs of enterprises. Therefore, in the course setting, the colleges should do in-depth investigation of enterprises, grasp the direction of market development, so that curriculum can not only meet the needs of the current enterprise development, but also take into account the future development trend of enterprises.

In the actual curriculum, the college needs to first understand the work skills of each trainee, and then set up related courses according to the skill demand, and combine the production characteristics of each trades to formulate relevant curriculum implementation plan of theoretical study and practical operation. And finally prepare an evaluation program to easy operate curriculum.

\subsection{Accelerating the Construction of New Teaching Staff}

In education, teachers are the key to the success of education reform. However, most of the current teachers in vocational schools in China are directly from job transformation of colleges and universities or secondary schools. Their prominent feature is the theoretical knowledge is very rich, but the practice of knowledge is relatively lacking. In order to make up for this deficiency, the vocational colleges can allow teachers to take turns to internship. During teachers' internship period, you can let the relevant technical backbone of the enterprise to teach practical skills courses in the school. This can not only improve the professional ability of teachers, but also improve the enterprise to participate in student training, teacher education and teaching ability. In order to further improve the teachers' adaptability to the teaching mode, schools can also organize leaders and key teachers to study abroad on advanced experience of vocational education, have the intuitive feel of foreign teaching mode. First of all, from the backbone of teachers, academic leaders to start, change the concept of vocational education, vocational education and optimize teaching methods, and then bring all the teachers into the vocational education reform.

\subsection{The Reform of the New Teaching Mode}

In the comparative analysis of vocational education in China and Germany, this thesis found that in the hardware facilities in practice China's vocational colleges is not lagged behind by Germany, but why the students' practical ability to operate it is relatively poor? After analysis, it is related to the school education model. [3] in Germany, more emphasis is on the subjectivity of students, teachers are teaching around the development of students' vocational skills, students are the core of learning, the implementation of the teacher is only as a guide role. In China, teaching has teachers as the main body, students only imitate teachers. There is lack of learning initiative, independence and creativity. Therefore, the implementation of new teaching model for teaching reform is very 
important.

In the actual teaching process, teachers can first guide students to understand the learning tasks, develop appropriate teaching objectives, and then co-concept, design the implementation of learning activities program. In the implementation process of the whole learning program, students should be the main body, when the students are in the process of learning difficulties, teachers can guide them. Finally, the teacher evaluates students' learning activities according to the situation, and analyzes the achievements and problems in the course of activities so as to improve the students' theoretical study level.

\section{References}

[1] Xie Chuanbing. Comparison of Vocational Education Law between China and Germany [J] .Jiangsu Education Research. 2008 (09)

[2] Feng Linna. German vocational education quality guarantee mechanism study [D] Shanxi Normal University. 2010

[3] Wang Ying. Chinese and German higher vocational education development: comparison and reference [D]. Wuhan University of Technology 2008 